An account of the progress of negro status during the past thirty-five years gives statistics relating to educational, economic, and religious progress in the U.S.A., and refers to improvements in the status and conditions of Africans in colonial territories in Africa; the special factors which have been mainly operative in recent developments are analysed under the categories of action by Governments, Educational Institutions, Foundations, Churches, Negro Service Associations, Publications, and Press. The chief obstacles in the way of further progress are described as ignorance on the part of whites, and extreme racism-both white and negro.

A section on the Racial Situation in Bantu Africa is contributed by Senator Rheinallt Jones.

\title{
International Conferences on Land Problems in Africa
}

Two conferences were held at Jos, Nigeria, in November 1949 , one to discuss land utilization and one concerned with indigenous rural economy. The first was a British conference under the Chairmanship of the Assistant Under-Secretary of State for the Colonies, at which representatives of France, Belgium, Portugal, the Union of South Africa, the United States, Southern Rhodesia, Anglo-Egyptian Sudan, and the Food and Agricultural Organization of the United Nations, were present as observers. The conference appointed five committees, whose findings were discussed at a plenary session; the systematic survey of soils in development areas was recommended, as well as the introduction of advanced methods of agriculture, and the formation of groups of peasant farmers to be established on unoccupied land under conditions favourable to the practice of good husbandry.

The International Conference on Indigenous Rural Economy was organized jointly by the United Kingdom, France, Belgium, Portugal, the Union of South Africa, and Southern Rhodesia. It recommended the wider dissemination and exchange of information on such subjects as water control, methods of food storage, processing of products within village communities, use of mechanical implements and artificial fertilizers, and the breeding of suitable grass strains. It also advocated the establishment of co-operative societies, and the emphasizing of crafts, industries, and agriculture in schools' curricula, and recorded the need for mote research in the field of microbiology.

\section{Semaines Sociales de France}

LA XXXVII ${ }^{e}$ Semaine Sociale se tiendrait à Nantes du mardi i 8 au dimanche 23 juillet. Elle traitera du 'Monde rural dans l'économie moderne'. Pour tous renseignements, s'adresser au Secrétariat Général des Semaines Sociales, I6 rue du Plat, Lyon 2, France.

\section{East African Institute of Social Studies, Makerere, Uganda}

Dr. Audrey I. Richards, M.A., Ph.D., Reader in Anthropology at the University of London and a senior member of the staff of the London School of Economics, has accepted the post of Director of the East African Institute of Social Studies and has recently taken up residence at Makerere.

Members of the Institute and readers of this journal will be well acquainted with Dr. Richards' gifts and attainments and her lively interest in African affairs. We are happy to record our appreciation of the many services she has rendered to this Institute as member of its Executive Council and of the Ethnographic Survey Committee, as contributor to Africa, and as a friend and supporter of long standing. Our good wishes for her success in this important post go with her. 